\title{
Jerky, a Protein Deficient in a Mouse Epilepsy Model, Is Associated with Translationally Inactive mRNA in Neurons
}

\author{
Wencheng Liu, ${ }^{1}$ Jeremy Seto, ${ }^{2}$ Gerald Donovan, ${ }^{3}$ and Miklos Toth ${ }^{1,2}$ \\ ${ }^{1}$ Department of Pharmacology, Weill Medical College and ${ }^{2}$ Graduate Program in Neuroscience, Weill Graduate School of \\ Medical Sciences, Cornell University, New York, New York 10021, and ${ }^{3}$ Gene Expression, Progenics Pharmaceuticals, \\ Tarrytown, New York 10591
}

\begin{abstract}
Temporal lobe epilepsy (TLE) is a common seizure disorder, but the underlying molecular mechanisms are unknown. We reported previously that inactivation of the jerky gene in mice causes recurrent limbic seizures highly similar to TLE. Electrophysiological studies showed abnormal firing in hippocampal neurons in these mice, but it is not known how a deficiency in the Jerky protein leads to neuronal hyperexcitability. Here we show that Jerky is a brain-specific protein with a high expression level in neurons. Jerky binds mRNAs with high affinity, and
\end{abstract}

Temporal lobe epilepsy (TLE) is the most common seizure disorder in adults. The typical form of TLE is often severe and is associated with hippocampal atrophy. Members of families with strong history of febrile seizures have an increased susceptibility to TLE, but genetic factors are not known to play a major role in the development of TLE (Falconer et al., 1964). Autosomal dominant TLE and autosomal dominant lateral TLE are hereditary and nonlesional forms of TLE with a relatively benign disease course (Berkovic et al., 1994, 1996; Saenz et al., 1999; Gambardella et al., 2000; Ikeda et al., 2000; Picard et al., 2000). Genetic analysis found a linkage to chromosome $10 \mathrm{q}$ for autosomal dominant lateral TLE, but these studies did not lead to the cloning of a gene (Poza et al., 1999).

We reported previously that "jerky" mice have recurrent limbic seizures (Toth et al., 1995; Donovan et al., 1997) that are highly reminiscent of those seen in familiar TLE (Berkovic et al., 1994, 1996; Cendes et al., 1998; Saenz et al., 1999; Gambardella et al., 2000; Ikeda et al., 2000; Picard et al., 2000). First, the inheritance of the seizure disorder is autosomal dominant in both human and mouse. Second, penetrance of seizures in both human and mouse is partial. Third, the symptoms usually disappear spontaneously by age in both species.

Seizures in "jerky" mice are caused by the lack of the jerky gene (Toth et al., 1995; Donovan et al., 1997). The mouse Jerky protein is encoded by a single exon (Toth et al., 1995), consisting of 557

\footnotetext{
Received Sept. 17, 2001; revised Oct. 10, 2001; accepted Oct. 11, 2001.

This work was supported by National Institutes of Health Grant R01NS34151 (M.T.), Cancer Pharmacology Training Grant T32 CA62948 (W.L.), and National Institute on Drug Abuse Grant DA 07274 (J.S.). We thank Drs. J. W. Hershey (Department of Biological Chemistry, School of Medicine, University of California, Davis, Davis, CA), K. Elkon (Hospital for Special Surgery, New York, NY), and M. Wiedmann (Cell Biology and Genetics, Sloan Kettering Institute, New York, NY) for the eIF3, P0, and S3 antibodies, respectively. We also thank C. Li (Rockefeller University, New York, NY) and S.W. Yun (Weill Medical College of Cornell University) for providing us primary rat and mouse neuronal cultures, respectively.

Correspondence should be addressed to Miklos Toth, Department of Pharmacology, Weill Medical College of Cornell University, 1300 York Avenue, LC 522, New York, NY 10021. E-mail: mtoth@mail.med.cornell.edu.

Copyright (ㄷ) 2001 Society for Neuroscience $\quad 0270-6474 / 01 / 220176-07 \$ 15.00 / 0$
}

it is a component of messenger ribonucleoprotein complexes in vivo. However, Jerky is not associated with ribosomes and actively translating mRNAs. These data suggest that Jerky may regulate $\mathrm{mRNA}$ use in neurons, and its deficiency could lead to perturbations in the regulated use of preexisting mRNAs.

Key words: Jerky; epilepsy; seizure; neuron; animal model; RNA binding protein; RNA-protein interaction; $m R N A$; translation

amino acid (aa) residues (GenBank accession number NM_008415). The similarity of Jerky to DNA transposons of the TC1/Pogo/Tigger family has been recognized (Toth et al., 1995). Although most DNA transposon copies are nonfunctional, transposon-like genes encoding proteins such as jerky and $C E N P-B$ (centromere binding protein-B) indicate that DNA transposons may have become fixed in the genome as functional genes (International Human Genome Sequencing Consortium, 2001). The human homolog of jerky (JRK/JH8) has also been cloned (Morita et al., 1998). A de novo nonconservative mutation to a potential glycosylation site in JRK/JH8 has been described recently in an epileptic patient (Moore et al., 2001).

Based on its similarity to CENP-B, a possible nuclear regulatory function has been hypothesized for Jerky (Toth et al., 1995). CENP-B is an abundant nuclear protein localized on the centromere (Earnshaw and Rothfield, 1985; Earnshaw et al., 1987; Cooke et al., 1990; Sullivan and Glass, 1991) and is implicated in the assembly of centromeric DNA (Muro et al., 1992; Yoda et al., 1992). In contrast to CEN P-B, Jerky is not exclusively localized to the nucleus (see Results) and may have a cytoplasmic function, in addition to a CENP-B-like nuclear role. Here we show that cytoplasmic Jerky is a constituent of translationally inactive messenger ribonucleoprotein (mRNP) particles in brain. Jerky may retain and mask mRNAs within mRNPs, and Jerky deficiency could lead to perturbations in the regulated use of preexisting mRNAs in neurons.

\section{MATERIALS AND METHODS}

Generation of glutathione S-transferase-Jerky fusion protein and polyclonal antibodies against Jerky. Recent sequence analysis of jerky mRNAs from brain indicated that the open reading frame (Toth et al., 1995) can be extended by 48 aa (sequence has been deposited to GenBank, accession number NM_008415), resulting in a protein of 557 residues. A glutathione $S$-transferase (GST)-tagged Jerky construct was generated by cloning a $1.65 \mathrm{~kb}$ cDNA, corresponding to full-length Jerky (1-557) in frame with an N-terminal GST tag. We first produced a jerky DNA fragment flanked by EcoRI sites by PCR using a 5' primer (GGAATTCCCAT GGCCTCCAA GCAGGCTGCA) encoding an EcoRI site and the first 
seven amino acids of Jerky, and a $3^{\prime}$ primer (CGGAATTCGTTGTCACCTGCAGTGGAAGA) corresponding to an EcoRI site and the last seven amino acids of Jerky. Then, the EcoRI fragment was cloned into the expression vector pGEX-6P2 (Amersham Pharmacia Biotech, Piscataway, NJ). This plasmid was transformed into BL21 Escherichia coli, and protein expression was induced by $1 \mathrm{~mm}$ isopropyl- $\beta$-D-thiogalactopyranoside. GST-Jerky was purified as described by Guan and Dixon (1991).

To produce antibodies in rabbits, $4 \mathrm{mg}$ of GST-Jerky was produced and sent to Strategic Biosolutions (Ramona, CA). These antibodies were affinity-purified with Jerky covalently bound to Sepharose beads (Amersham Pharmacia Biotech). The antibody recognized a $62 \mathrm{kDa}$ protein in brain (see Fig. 1A). The size of this immunoreactive band is in a good agreement with the predicted molecular mass of $62.5 \mathrm{kDa}$ of the Jerky protein. The antibody also recognized Jerky expressed in HEK 293 cells as a protein tagged with Flag (see Fig. $3 C$ ) and V5 (data not shown) epitopes.

$R N A$ labeling. Labeled mRNA fragments were obtained by using the RNA SELEX procedure of Dobbelstein and Shenk (1995), modified in our laboratory. Briefly, first-strand cDNA synthesis was initiated from mouse brain mRNA (Clontech, Palo Alto, CA) by using a primer with a random octamer at its $3^{\prime}$ end (SELEX 1 primer, 5'-AGCAACAGCAAGACTACGAGTGANNNNNNNNN-3'). Second strand was generated by using another primer containing a random hexamer at its $3^{\prime}$ end (SELEX 2 primer, 5'-GGGAGCTCAGAATAAACGCTCAANNNNNN-3'). The second strand was PCR amplified with SELEX 1 primer without the random sequence (SELEX 1b, 5'-AGCAACAGCAAGACTACGAGTGA-3') and SELEX 2 primer without the random hexamer but with a T7 promoter sequence at the $5^{\prime}$ end (SELEX2-T7, 5'-GACAGCATTAATACGACTCACTATAGGGAGCTCAGAATAAACGCTCAA$\left.3^{\prime}\right)$. The resulting PCR products were used to synthesize RNA probes by T7 polymerase in the presence of $\left[\alpha^{-32} \mathrm{P}\right] \mathrm{UTP}$ (DuPont NEN, Boston, MA). RNA homopolymers (Sigma, St. Louis, MO) were $5^{\prime}$ end labeled by T4 kinase and $\left[\alpha{ }^{32} \mathrm{P}\right] \mathrm{ATP}$.

Gel electrophoresis and Western analysis. Mouse brains were isolated and homogenized in hypotonic buffer $(10 \mathrm{~mm}$ Tris, $\mathrm{pH} 7.5,50 \mathrm{mM} \mathrm{KCl}$, $5 \mathrm{mM} \mathrm{MgCl}_{2}$, and $0.1 \% \mathrm{NP} 40$ ) containing $1 \mathrm{mM}$ PMSF, $0.2 \mu \mathrm{g} / \mathrm{ml}$ aprotinin, $40 \mu \mathrm{g} / \mathrm{ml}$ bestatin, and $0.5 \mu \mathrm{g} / \mathrm{ml}$ leupeptin (Roche, Indianapolis, IN). The homogenate was centrifuged at $10,000 \times g$ for $20 \mathrm{~min}$, and the supernatant was collected. The protein concentration of the supernatant was determined using BCA protein assay (Pierce, Rockford, IL). Samples $(20 \mu \mathrm{g}$ of the total protein) were separated on $7.5 \%$ polyacrylamide gels and transferred onto polyvinylidene difluoride (PVDF) membranes (Millipore, Bedford, MA). Western analysis was performed as described by Liu et al. (1995). In these assays, a dilution of 1:1000 of affinity-purified anti-Jerky antibodies was used, and the signal was detected by enhanced chemiluminescence (Pierce). Some of the blots were also probed by 1:1000 dilution of a human autoimmune serum containing anti P0 antibody (obtained from Keith Elkon, Hospital for Special Surgery, New York, NY).

Hippocampal primary neuronal cultures and immunocytochemistry. Primary neuronal cultures were prepared from the hippocampus of embryonic day 18 Sprague Dawley rat embryos as described by Papa et al. (1995). In brief, hippocampus was dissected in cold Leibovitz's 15 (L15) medium. The tissue was mechanically dissociated in L15 medium using polished Pasteur pipettes. Tissue was then suspended in DMEM containing $10 \%$ fetal calf serum, $2 \%$ of B27 supplement (Life Technologies, Gaithersburg, MD), $2 \mathrm{~mm}$ glutamine, and penicillin-streptomycin. Rat hippocampal cells were plated on round glass coverslips coated with poly-L-lysine. Four days after plating, the medium was replaced with DMEM containing 5\% fetal calf serum, and incubation continued for an additional $3 \mathrm{~d}$. Seven-day-old cultures were processed for immunohistochemistry. Cells were incubated with $3.5 \%$ paraformaldehyde in PBS (in mM: $137 \mathrm{NaCl}, 4.3 \mathrm{Na}_{2} \mathrm{HPO}_{4}, 2.7 \mathrm{KCl}$, and $1.4 \mathrm{KH}_{2} \mathrm{PO}_{4}$ ) for $15 \mathrm{~min}$, washed with PBS three times, and then incubated with $5 \%$ goat serum in PBS- $-2.2 \%$ Triton X-100 (PBST) for $1 \mathrm{hr}$. Incubation was followed by adding primary antibodies [1:100 for affinity-purified anti-Jerky antibodies and 1:500 for anti- $\beta$-tubulin (TuJ1)] in PBST containing 1\% goat serum at $4^{\circ} \mathrm{C}$ overnight. Next, cells were washed three times with PBS and then incubated with anti-rabbit-FITC or biotinylated anti-mouse antibodies in PBST for $1 \mathrm{hr}$ at room temperature. Finally, cells were washed with PBS and incubated with avidin-rhodamine (1:500; Vector Laboratories, Burlingame, CA) in PBST for $1 \mathrm{hr}$ at room temperature and washed three times with PBS before mounting with Fluoromount
(Electron Microscopy Sciences, Ft. Washington, PA). Cells were examined using a Zeiss (Oberkochen, Germany) confocal microscope.

Sucrose gradient centrifugation and Western analysis. Cerebral cortices from mice were rapidly removed after decapitation and placed into 0.32 $\mathrm{M}$ sucrose solution containing $4 \mathrm{~mm}$ HEPES, $\mathrm{pH} 7.3,5 \mathrm{mM} \mathrm{MgCl}_{2}$ (or 30 mM EDTA), $1 \mathrm{~mm}$ PMSF, $0.2 \mu \mathrm{g} / \mathrm{ml}$ aprotinin, $40 \mu \mathrm{g} / \mathrm{ml}$ bestatin, 0.5 $\mu \mathrm{g} / \mathrm{ml}$ leupeptin, $1 \mathrm{~mm}$ DTT , and $30 \mathrm{U}$ of RNasin (Promega, Madison, WI). In some experiments, $300 \mu \mathrm{g} / \mathrm{ml}$ RNaseA was added to the samples. To arrest polysome migration, tissue was incubated on ice for $20 \mathrm{~min}$ in the presence of $200 \mu \mathrm{g} / \mathrm{ml}$ cycloheximide. Samples were gently homogenized (10 strokes) with a glass homogenizer, and homogenates were centrifuged at $4000 \times g$ for $15 \mathrm{~min}$. Supernatants were then collected and loaded onto $5-25 \%$ sucrose gradients, followed by centrifugation at $39,000 \mathrm{rpm}$ for $100 \mathrm{~min}$ at $4^{\circ} \mathrm{C}$. Twenty-three fractions were collected from each gradient. Each fraction was divided into two equal portions, one for RNA analysis and the other for protein analysis. For the RNA analysis, samples were phenol-chloroform extracted once, and the RNA was ethanol precipitated. The RNA was electrophoresed in a formaldehyde agarose gel, and the rRNA was visualized with ethidium bromide. For protein analysis, samples were first concentrated using Ultrafree- 0.5 concentrators (Millipore). One-third of the concentrated sample was loaded onto $12.5 \%$ acrylamide gels and transferred onto PVDF membranes. Western analysis was performed as described above.

Isolation of $m R N P$ complexes by oligo-dT beads. mRNP complexes were isolated as described by Feng et al. (1997). One mouse brain was homogenized in $1 \mathrm{ml}$ of lysis buffer containing $20 \mathrm{~mm}$ Tris, pH7.5, 100 $\mathrm{mm} \mathrm{KCl}, 5 \mathrm{~mm} \mathrm{MgCl}$, $0.3 \% \mathrm{NP}-40,200 \mathrm{U}$ of rRNasin (Promega), and Complete Protease inhibitor cocktail (Roche). Post-mitochondrial supernatants were isolated by centrif ugation at $10,000 \times g$ for $10 \mathrm{~min}$. Aliquots $(200 \mu \mathrm{l})$ were applied to $40 \mu \mathrm{l}$ Oligotex beads (Qiagen, Valencia, CA). Samples were incubated in binding buffer in the presence of either competitive poly $\left(\mathrm{A}^{+}\right)(40 \mathrm{pmol})$, RNaseA (30 U), and $\mathrm{RNaseT}_{1}(30 \mathrm{U})$, or $\mathrm{ddH}_{2} 0$. After a 15 min incubation at $37^{\circ} \mathrm{C}$, samples were centrifuged at $10,000 \times g$ and washed three times in $500 \mu$ l of low-salt buffer. Samples were finally thermo-eluted with preheated elution buffer. Aliquots, representing $1,1,3$, and $50 \%$ of load, flow-through, combined washes, and eluate, respectively, were used for Western analysis.

Isolation of Jerky-containing cytoplasmic complexes by immunoprecipitation. Pull-down of Jerky complexes was performed essentially as described by Ceman et al. (1999). Briefly, $1 \times 10^{9}$ HEK 293T cells were transfected with a Flag-tagged Jerky construct. After $24 \mathrm{hr}$, cells were harvested and washed three times with 10 vol of PBS. Cells were then lysed mildly with lysis buffer (50 mM Tris, pH7.5, $150 \mathrm{~mm} \mathrm{NaCl}, 30 \mathrm{~mm}$ EDTA, and $0.5 \%$ Triton X-100) containing Complete Protease inhibitor cocktail for $45 \mathrm{~min}$ on ice. Nuclei were pelleted at $3000 \times g$ for $10 \mathrm{~min}$ at $4^{\circ} \mathrm{C}$. The cytoplasmic supernatant was precleared for $2 \mathrm{hr}$ with $250 \mu \mathrm{l}$ of Flag peptide $(250 \mathrm{mg})$ - anti-Flag antibody complex immobilized on agarose bead (Sigma). After centrifugation, the supernatant was immunoprecipitated with $200 \mu \mathrm{l}$ of anti-Flag agarose bead for $3 \mathrm{hr}$. The immunoprecipitated material was recovered by centrifugation and washed twice with $1 \mathrm{ml}$ of lysis buffer for $15 \mathrm{~min}$ at $4^{\circ} \mathrm{C}$. Then, the material was washed again with lysis buffer containing $50 \mathrm{U}$ of RNase-free DNase I (Roche) in the presence of $200 \mathrm{U}$ of rRNasin (Promega). Finally, the immunoprecipitated material was washed with lysis buffer containing 200 $\mathrm{U}$ of RNasin and pelleted by gravity overnight. Protein-RNA complexes were eluted with a mixture of $150 \mu \mathrm{l}$ of lysis buffer and $150 \mu \mathrm{l}$ of Flag peptide $(5 \mathrm{mg} / \mathrm{ml})$ for $45 \mathrm{~min}$. The supernatant containing the eluted complexes was recovered by centrifugation. Elution was continued with $500 \mu \mathrm{l}$ of lysis buffer for $45 \mathrm{~min}$. The eluates were combined, and $10 \%$ of this fraction was used for protein analysis. To recover the RNA content from the complexes, the rest of the sample was incubated with lysis buffer containing $100 \mu \mathrm{g}$ of proteinase $\mathrm{K}$ (Life Technologies) and $200 \mathrm{U}$ of RNasin at $37^{\circ}$ for $15 \mathrm{~min}$. The sample was then phenol-chloroform extracted, and the mRNA was ethanol precipitated.

Assays to test Jerky-RNA interaction. Full-length GST-Jerky $(0.5 \mu \mathrm{g})$ in RNA binding buffer (150 mm LiCl, $10 \mathrm{~mm}$ Tris, $\mathrm{pH} 7.5$, and 1 mM EDTA) was loaded onto poly(A), poly $(\mathrm{U})$, poly $(\mathrm{C})$, or $\operatorname{poly}(\mathrm{G})$ agarose columns (Sigma). The columns were washed with 20 column volume of RNA binding buffer. Bound Jerky was eluted twice with $500 \mu$ l of elution buffer (1 $\mathrm{m} \mathrm{NaCl}, 10 \mathrm{~mm}$ Tris, $\mathrm{pH}$ 7.5, $1 \mathrm{~mm}$ EDTA, and 0.1\% Triton X-100). Eluates were concentrated with Ultrafree- 0.5 concentrators (Millipore) Concentrated samples were subjected to SDS-PAGE and Western analysis using anti-Jerky antibodies as described above.

In other experiments, mouse brain mRNA (Clontech) was incubated with GST-Jerky immobilized on agarose beads for $20 \mathrm{~min}$ in RNA 
A

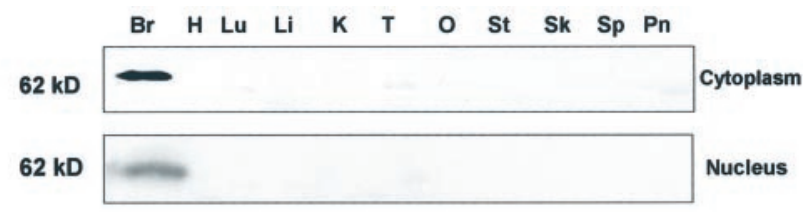

B

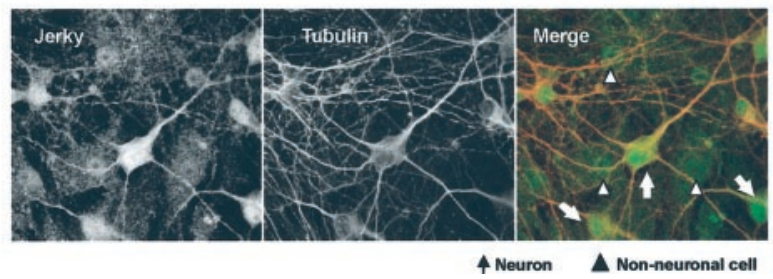

Figure 1. Expression of Jerky in mouse tissues and rat hippocampal cultures. $A$, Western analysis of cytoplasmic and nuclear fractions from mouse tissues by Jerky antibody. $\mathrm{Br}$, Brain; $H$, heart; $L u$, lung; $L i$, liver; $K$, kidney; $T$, testes; $O$, ovary; $S t$, stomach; $S k$, skeletal muscle; $S p$, spleen; $P n$, pancreas. $B$, Double-immunostaining of neuronal cultures by anti-Jerky (left panel; green on the merged image on the right) and anti- $\beta$-tubulin (middle panel; red on the merged image on the right) antibodies. Arrows and arrowheads indicate neuronal ( $\beta$-tubulin-positive) and non-neuronal ( $\beta$-tubulin-negative) cells, respectively.

binding buffer at room temperature. Beads were washed twice with RNA binding buffer for $15 \mathrm{~min}$. Bound mRNA was recovered by phenolchloroform extraction, followed by ethanol precipitation, and was used for first-strand cDNA synthesis with oligo-dT primer in the present of $\left[\alpha-{ }^{32} \mathrm{P}\right] \mathrm{dCTP}$. Also, labeled mRNA was interacted with Jerky immobilized on nitrocellulose membrane. GST-Jerky $(0.2 \mu \mathrm{g})$ was applied per well onto a $0.45 \mu \mathrm{M}$ nitrocellulose membrane in a slot blot system (BA85; Schleicher \& Schuell, Keene, NH). Filters were incubated with ${ }^{32} \mathrm{P}$ labeled mRNA fragments $\left(2 \times 10^{6} \mathrm{cpm} / \mathrm{ml}\right)$ in binding buffer $(50 \mathrm{~mm}$ $\mathrm{NaCl}, 10 \mathrm{~mm}$ Tris, $\mathrm{pH} 7.5,10 \mathrm{~mm} \mathrm{MgCl}_{2}, 1 \mathrm{~mm}$ EDTA, $1 \mathrm{~mm}$ DTT, and $0.02 \% \mathrm{BSA}$ ) for $2 \mathrm{hr}$ at $25^{\circ} \mathrm{C}$. After incubation, filters were washed twice with binding buffer for $30 \mathrm{~min}$ each. Bound radioactivity was visualized by autoradiography.

Filter binding assays were performed as described by Hall and Kranz (1999). First, mouse brain mRNAs were preselected with GST-Jerky immobilized on glutathione beads, and the mRNA was labeled by the modified RNA SELEX procedure as described above. Labeled mRNA fragments were incubated with serial dilutions of purified GST-Jerky in a buffer containing $50 \mathrm{~mm} \mathrm{LiCl}, 10 \mathrm{mM} \mathrm{MgCl}_{2}, 10 \mathrm{~mm}$ Tris, $\mathrm{pH} 7.5,20$ $\mu \mathrm{g} / \mathrm{ml} \mathrm{BSA}$, and $1 \mathrm{~mm}$ EDTA for $30 \mathrm{~min}$ at room temperature. RNAprotein complexes were then filtered through a sandwich of a $0.45 \mu \mathrm{m}$ nitrocellulose membrane (BA85; Schleicher \& Schuell) on the top and a nylon membrane (Nytran; Schleicher \& Schuell) on the bottom. Bound and unbound radioactivity on the nitrocellulose and nylon filters, respectively, was measured by a STORM 860 phosphorimage analyzer (Molecular Dynamics, Sunnyvale, CA), and $K_{\mathrm{D}}$ was calculated as described by Hall and Kranz (1999).

\section{RESULTS}

\section{The Jerky protein is exclusively expressed in brain}

Antibody produced in rabbits against recombinant Jerky (see Materials and Methods) was used to determine the tissue-specific expression of Jerky in mice. Tissue distribution of Jerky was studied in both nuclear and cytoplasmic fractions of the tissues. Western blots showed a $62 \mathrm{kDa}$ immunoreactive band in brain in both the cytoplasmic and nuclear fractions (Fig. 1 $A$ ). The size of this immunoreactive band is in a good agreement with the predicted molecular mass of $62.5 \mathrm{kDa}$ of the Jerky protein (GenBank accession number NP_032441). The antibody also recognized Jerky in rat brain (data not shown). Heart, liver, kidney, ovary, stomach, skeletal muscle, spleen, and pancreas showed no detectable immunoreactivity. In testis and lung, a weak immunoreactive band with an $\sim 58 \mathrm{kDa}$ mass was seen occasionally. It is not clear

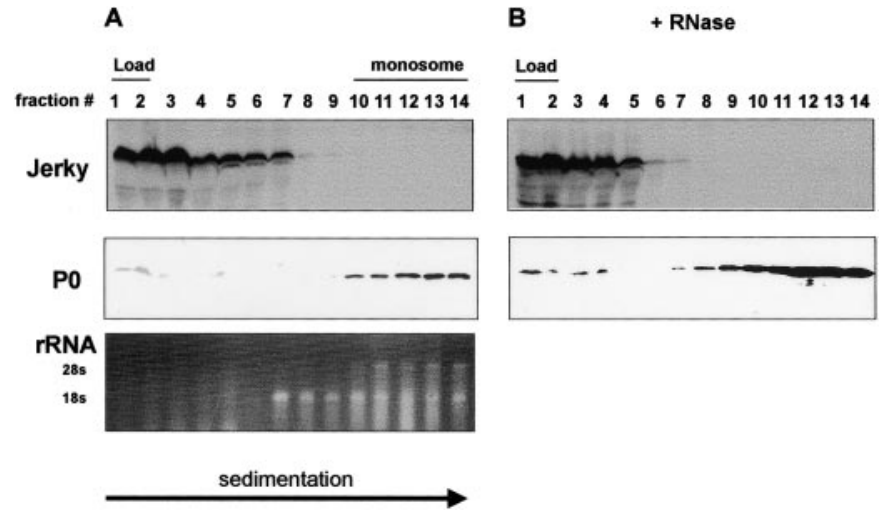

Figure 2. Jerky comigrates with mRNP in $5-25 \%$ sucrose gradient. $A$, Jerky (top panel) and P0 (middle panel) immunoreactivity in gradient fractions derived from mouse brain cytoplasmic extracts. The bottom panel shows the distribution of rRNA in the fractions. Analysis of the top 14 fractions of the total of 23 fractions is displayed. B, Jerky (top panel) and P0 (middle panel) immunoreactivity in gradient fractions derived from RNase-digested cytoplasmic extract. No intact 18 and 28S rRNAs were seen after RNase treatment (data not shown).

whether these represent a Jerky isoform or a cross-reactivity of the antibody in these tissues.

\section{Jerky is highly expressed in primary neurons}

Jerky was immunolocalized with the polyclonal antibody in 1-week-old primary rat hippocampal cultures (Fig. 1B). Neurons were identified by staining with a $\beta$-tubulin antibody. Jerky immunostaining was strong in neurons and appeared to be granular. Consistent with the Western analysis shown in Figure $1 A$, Jerky was present in both the nucleus and cytoplasm (Fig. $1 B$ ). Immunostaining was also seen in the nucleus and the cytoplasm of non-neuronal ( $\beta$-tubulin-negative) cells, but it was considerably weaker than in neurons.

\section{Jerky comigrates with mRNP complexes in sucrose density gradient}

Because of the similarities between Jerky and the heterochromatin-associated CENP-B (see introductory remarks), the presence of Jerky in nuclear brain fraction and in the nuclei of neurons was not surprising. However, the presence of Jerky immunoreactivity in cytoplasmic brain fractions and in the cytoplasm of primary neurons was unexpected, and we further studied this unique feature of Jerky. Specifically, a possible association of Jerky with macromolecular complexes in brain cytoplasmic lysates was investigated by sedimentation analysis in 5-25\% sucrose gradients (Fig. $2 A$, top panel). A significant portion of Jerky entered the gradient (fractions 1 and 2 represent soluble Jerky remaining on the top of the gradient) and was found in complexes with a sedimentation up to the $80 \mathrm{~S}$ monosomes. The position of monosomes in the gradient was indicated by the presence of the 18 and 28S rRNAs, as well as the large ribosome subunit protein P0 (Fig. $2 A$, middle and bottom panels). Jerky was not detected in fractions containing polysomes (fractions 15-23; not shown in figure). Jerky was not found in association with polysomes either when polysomes were better resolved on $25-47 \%$ gradients (data not shown). A small fraction of the Jerky protein (Fig. $2 A$, top panel, fraction 7) cosedimented with the $40 \mathrm{~S}$ small ribosomal subunit (indicated by the presence of the $18 \mathrm{~S}$ ribosomal RNA in Fig. $2 A$, bottom panel ). However, Jerky is probably not associated with the $40 \mathrm{~S}$ ribosomal subunit because immunoprecipitation of 


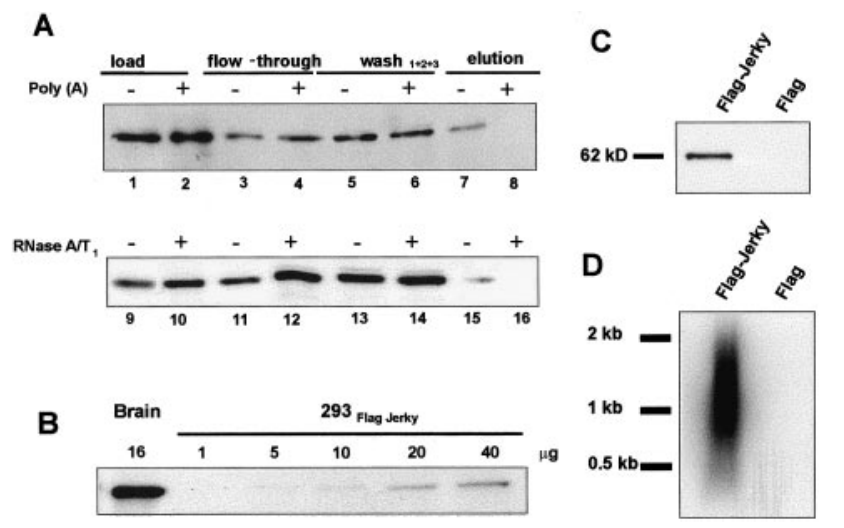

Figure 3. Association of Jerky with mRNP. A, Western analysis of brain lysates subjected to a selection with oligo-dT polystyrene latex beads. Selection was performed in the absence $(-)$ and presence $(+;$ top panel $)$ of poly $\left(\mathrm{A}^{+}\right)$or after RNaseA or $\mathrm{RNaseT}_{1}$ treatment (+; bottom panel). Samples from load (lanes 1, 2, 9, 10; $1 \%$ of total load), flow-through (lanes $3,4,11,12 ; 1 \%$ of total), combined wash fractions (lanes $5,6,13,14 ; 3 \%$ of total), and eluate (lanes $7,8,15,16 ; 50 \%$ of total) were analyzed by anti-Jerky antibodies. $B$, Jerky content of brain and HEK 293T cytoplasmic extracts. Western blots containing cytoplasmic extracts from brain and HEK 293T cells expressing Flag-tagged Jerky were probed by antiJerky antibody. $C$, Immunoprecipitation from cytoplasmic extract of FlagJerky-expressing HEK 293 T cells by an anti-Flag monoclonal antibody (left lane). Control immunoprecipitation from cytoplasmic extract of HEK 293T cells transfected with a Flag peptide expressing plasmid (right lane). Five percent of the immunoprecipitated materials was analyzed by Western blotting using anti-Jerky antibodies. $D$, mRNA content of Flag immunocomplexes (30\% of total) from HEK 293T cells transfected with Flag-Jerky and Flag-expressing plasmids. mRNA is visualized by reverse transcribing the RNA purified from the immunocomplexes.

these complexes via S3 (a small ribosomal subunit protein) did not pull down Jerky (data not shown). We concluded that Jerky was positioned in the gradient in fractions that contain complexes characterized by a sedimentation of $<80$ S. Typically, these fractions contain translationally inactive $\mathrm{mRNP}$ complexes but also other macromolecular complexes, such as proteasomes. We also concluded that Jerky is not associated with ribosomes.

Enzymatic treatment of brain cytoplasmic lysates with RNaseA before sedimentation resulted in a shift toward lower sedimentation of Jerky (Fig. 2, compare $A, B$ ), indicating that RNA is present and has a vital structural role in Jerky-containing macromolecular complexes. The RNaseA-induced leftward shift ( 2 fractions, representing $1 \mathrm{ml}$ of the $11.5 \mathrm{ml}$ gradient) of Jerky immunoreactivity was reproducible in three independent experiments. The level of $\mathrm{P} 0$ protein was increased in monosomal fractions in RNase-treated samples, indicating that polysomes were also disrupted by the enzyme (Fig. $1 B$, middle panel). Also, $\mathrm{P} 0$ protein appeared in soluble and low sedimentation fractions, indicating some disintegration of the monosomes and/or ribosome subunits.

\section{Jerky is present in mRNA-containing cytoplasmic complexes}

To further test the presence of Jerky in mRNPs, these particles were captured from brain extract (Fig. $3 A$ ). Although with low efficiency, mRNPs can be isolated by oligo-dT beads from cellular extract (Feng et al., 1997). As shown in Figure $3 A$, lane 7, Jerky was captured from cytoplasmic brain extract by oligo-dT polystyrene latex beads. Preincubation of oligo-dT beads with poly $\left(\mathrm{A}^{+}\right)$ prevented the binding of Jerky-containing cytoplasmic complexes to the beads (Fig. 3A, lane 8), demonstrating that Jerky was captured via mRNA and not by another interaction. As expected,
A

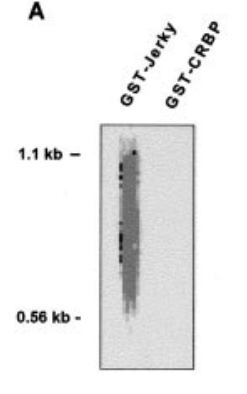

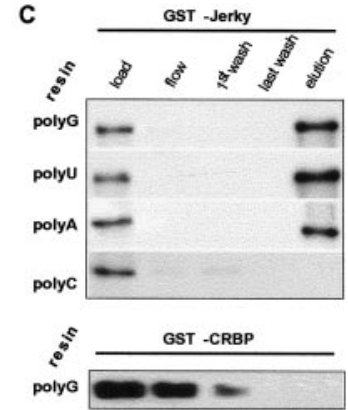

Figure 4. Direct interaction of Jerky with mRNA. A, Interaction of brain mRNA with GST-Jerky immobilized on beads. Bound mRNA is visualized by reverse transcription. GST-CRBP is the control protein. $B$, Interaction of labeled brain mRNA fragments and end-labeled ribopolymers with GST-Jerky immobilized on a nitrocellulose membrane. Bottom panel is a Western analysis of immobilized GST-Jerky and GST-CRBP by anti-GST antibodies to demonstrate the presence of proteins on the filter. $C$, Interaction of GST-Jerky with ribopolymers immobilized on beads. $1 / 100,1 / 100,1 / 100,1 / 15$, and $1 / 15$ of the available materials from load, flowthrough, wash, final wash, and eluate, respectively, are analyzed by Western blot using anti-GST antibodies. GST-CRBP is used as the negative control.

Jerky was not present in the eluate when the brain lysate was pretreated with RNaseA and $\mathrm{RNaseT}_{1}$ (Fig. 3A, lane 16). These data indicate that Jerky is present in mRNP particles in mouse brain.

We also determined whether mRNAs can be detected in cytoplasmic Jerky complexes. HEK 293T cells were transfected with plasmids expressing Flag-tagged Jerky. Similar to the subcellular compartmentalization of Jerky in brain (Fig. 1A), Flag-Jerky showed an approximately equal distribution in 293T cytoplasmic and nuclear extracts (data not shown). As a control, an expression vector containing the Flag tag alone was used. Importantly, Jerky was not expressed in an exceedingly large amount in HEK $293 \mathrm{~T}$ cells that could produce artificial interactions, because $16 \mu \mathrm{g}$ of brain cytoplasmic extract contained more Jerky than $40 \mu \mathrm{g}$ (normalized to the $40 \%$ transfection efficiency) of HEK $293 \mathrm{~T}$ cell extract (Fig. 3B). Indeed, HEK 293 T cells expressed Jerky at a relatively low level, especially when considering that neurons with high Jerky expression represent only a fraction of cells in brain. After transfection of HEK 293 T cells, Flag-containing complexes were pulled down from cytoplasmic extracts by a monoclonal anti-Flag antibody. The presence of Jerky in Flag immunocomplexes derived from Flag-Jerky but not Flag-expressing cells was verified by polyclonal Jerky antibody (Fig. 3C). The mRNA content of these complexes was tested by reverse transcription initiated by oligo-dT primer in the presence of labeled dATP. As Figure $3 D$ shows, mRNA was detected in Flag-Jerky but not in Flag immunocomplexes.

\section{Jerky can directly bind mRNAs}

Although the presence of Jerky in mRNP particles indicated an association between Jerky and mRNA, it was not known whether this interaction is direct or indirect. RNA binding of Jerky was assessed by incubating mouse brain mRNAs with Jerky immobilized on agarose beads (Fig. 4A). Recombinant and purified Jerky (GST-Jerky) was used in these experiments to ascertain that RNA binding does not occur via contaminating proteins. Bound mRNA was detected by reverse transcription. As Figure $4 A$ shows, labeled cDNA was obtained from Jerky but not control 


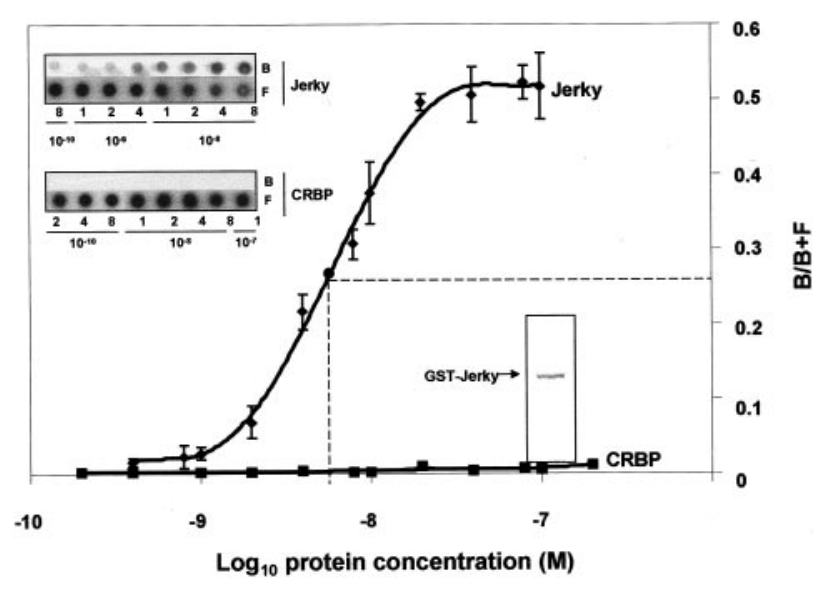

Figure 5. High-affinity binding of mRNA by Jerky. Filter binding assay with GST-Jerky and labeled mouse brain mRNA fragments. GST-CRBP is used as a control. The result is from four independent experiments, three of them performed in duplicate. Dotted lines represent $50 \%$ binding. Autoradiography of a representative set of filters with bound $(B)$ and free $(F)$ RNA is displayed on the top left corner. Coomassie blue staining of the GST-Jerky preparation after PAGE is displayed on the bottom right corner.

beads that contained cytosolic retinol binding protein (CRBP), a protein not known to bind RNA.

In a similar experiment, labeled RNAs were incubated with Jerky immobilized on nitrocellulose filters. RNA fragments copied from mouse brain mRNAs (see Materials and Methods), as well as synthetic RNA homopolymers $[\operatorname{poly}(\mathrm{A})$, poly $(\mathrm{C})$, poly $(\mathrm{G})$, and poly $(\mathrm{U})]$ were used (Fig. $4 B$ ). Similar to the previous experiment (Fig. 4A), mRNAs were retained on immobilized Jerky, suggesting again that brain mRNA can directly bind to Jerky. Homopolymers, except poly $(\mathrm{C})$, were also retained by Jerky. CRBP, which was immobilized in comparable amounts as Jerky on the filters (Fig. 4B, bottom, Anti-GST), retained no RNA (Fig. 4B, right lanes).

Finally, we performed the reverse experiment when Jerky was in solution and the RNA was immobilized. Specifically, GSTJerky was incubated with each of the four RNA homopolymers $[\operatorname{poly}(\mathrm{A}), \operatorname{poly}(\mathrm{C}), \operatorname{poly}(\mathrm{G})$, and $\operatorname{poly}(\mathrm{U})]$ covalently linked to agarose (Fig. $4 C$ ). At least $15 \%$ of Jerky was retained on poly(A) and poly $(\mathrm{G})$ and somewhat more on poly $(\mathrm{U})(1 / 15$ of the eluates contained equal amounts or more Jerky than $1 / 100$ of the loads). Binding to poly $(\mathrm{C})$ was not detected. These data indicated that the affinity of Jerky to RNA homopolymers is $\mathrm{U}>\mathrm{G}=\mathrm{A}$ (Fig. $4 C)$. GST-CRBP, used as a control, was not retained by poly $(\mathrm{G})$ (Fig. 4C, bottom panel).

Although these experiments suggested that Jerky can directly bind mRNA, the tests used were not suitable to determine whether the affinity of the binding is high enough to be considered physiologically relevant. To address this question, filter binding assays were performed with labeled mRNA fragments and recombinant Jerky. Increasing amounts of GST-Jerky were incubated with constant amounts of ${ }^{32} \mathrm{P}$-labeled mRNA fragments in solution and filtered through a sandwich consisting of a nitrocellulose membrane that retained RNA-protein complexes [bound fraction $(B)$ ] and a nylon membrane that retained unbound [free $(F)$ ] RNA (Fig. 5, inset at top left). The purity of the Jerky preparation was assessed by staining the gel with Coomasssie blue (Fig. 5, inset at bottom right), which showed an $\sim 90 \mathrm{kDa}$ protein (62 kDa Jerky fused to the $26 \mathrm{kDa}$ GST) but not other proteins.
Measuring both bound and free radioactivity allowed us to calculate binding affinity. As Figure 5 shows, the $K_{\mathrm{D}}$ of the binding by Jerky was $\sim 5 \mathrm{nM}$, representing a high-affinity binding. This is comparable with the binding of other RNA binding proteins with known biological function in RNA processing, such as HIV-1 tat (Dingwall et al., 1990), HuR (Nabors et al., 2001), Sam68 (Lin et al., 1997), and many others.

\section{DISCUSSION}

\section{Jerky is a brain-specific protein, with a preferential expression in neurons}

In agreement with the neurological phenotype of the "jerky" mice, the Jerky protein is expressed in the brain. The brainspecific expression of the Jerky protein was unexpected because we found previously that, besides the brain, jerky mRNA was also detectable in various other mouse tissues by reverse transcriptionPCR (Donovan et al., 1997). Northern analysis with poly $\left(\mathrm{A}^{+}\right)$ mRNA confirmed the widespread expression of jerky mRNA in mouse tissues (data not shown). These data suggest that the brainspecific expression of the Jerky protein is controlled at the translational level. Additional studies will be needed to clarify the nature of this regulation. Presence of the Jerky protein in brain is primarily attributable to neuronal expression, although a lower expression was also detectable in non-neuronal cells. No other tissue expressed the $62 \mathrm{kDa}$ Jerky protein in detectable amount, suggesting that the function(s) of the protein is limited to the nervous system.

Based on sequence similarity between Jerky and the heterochromatin-associated CENP-B, Jerky was expected to be an exclusively nuclear protein. Instead, we found that Jerky is approximately equally distributed between the nucleus and cytoplasm in hippocampal neurons. A similar distribution was found in HEK 293 cells expressing Flag-Jerky and V5-Jerky (data not shown). The presence of Jerky in the cytoplasm was not attributable to leakage from the nucleus during the immunostaining procedure because a nucleocytoplasmic distribution was also seen in vivo in GFP-Jerky-expressing HEK 293 cells (data not shown). Furthermore, Jerky showed a similar compartmentalization in brain in fractionation studies whether in the presence or absence of detergents. These data raised the possibility that Jerky may have a CENP-B-like function in the nucleus and an entirely new function in the cytoplasm.

CENP-B is believed to play a role in mitosis and/or meiosis. However, deletion of CENP-B in mice causes no apparent defect in mitosis and meiosis. Phenotypically, a moderate impairment in growth rate and disturbances in sexual functions have been found on some but not other genetic backgrounds (Hudson et al., 1998; Kapoor et al., 1998; Perez-Castro et al., 1998; Fowler et al. 2000). The mild phenotype of CENP-B knock-out mice is surprising because deletion of other centromeric proteins, such as Cenpa and Incenp, leads to embryonic lethality (Cutts et al., 1999; Howman et al., 2000). Interestingly, homozygote Jerky-deficient mice also show growth retardation and sexual dysfunction. These data would also be consistent with the idea of an overlapping CENP-B and nuclear Jerky function. A deficiency in Jerky, however, results in recurrent seizures, a unique phenotype not noticed in CENP-B knock-out mice. Moreover, this phenotype is related to a dosage-dependent (haplo-insufficient) function of Jerky because heterozygotes already display seizures. We reasoned that, whereas a deficiency in nuclear Jerky may be effectively compensated by CENP-B, an uncompensated loss of cytoplasmic Jerky could result in seizures. Although a role for nuclear 
Jerky cannot be excluded in seizure induction, we first focused on the role of Jerky in the cytoplasm.

\section{Jerky is part of mRNP particles}

mRNAs in cells are either translationally active or inactive. Whereas translationally active mRNAs are associated with ribosomes, translationally inactive mRNAs are found in mRNPs. mRNP particles have a slower sedimentation than the $80 \mathrm{~S}$ monosomes in sucrose gradients and are believed to represent stored mRNA or mRNA in transit to the ribosome. Several lines of evidence indicate that Jerky is part of mRNPs in brain. First, Jerky-containing macromolecular complexes cosediment with mRNP particles in sucrose gradients. Second, RNase treatment disrupts the integrity of these Jerky-containing particles. Third, mRNP complexes captured on oligo-dT beads contain Jerky. Together, these data indicate that Jerky is associated with mRNP particles containing translationally inactive mRNAs.

Although these data indicated the coexistence of mRNAs and Jerky in mRNPs, it was not known whether Jerky is directly involved in mRNA binding within these particles. Various in vitro binding assays with purified recombinant Jerky demonstrated that Jerky can bind mRNAs, as well as RNA homopolymers, with the exception of poly $(C)$. Additional filter binding experiments with Jerky-preselected mRNAs showed a high-affinity interaction between Jerky and mRNA, suggesting that this interaction can be biologically relevant. The low nanomolar binding affinity of Jerky for selected mRNAs is comparable with or exceeds the binding affinity of known RNA binding proteins, such as HIV-1 tat (Dingwall et al., 1990), HuR (Nabors et al., 2001), and Sam68 (Lin et al., 1997). It is important to note that only a fraction of mRNAs was observed to be bound to Jerky, even if the protein was in large excess (data not shown). This indicates that Jerky is not a "global" mRNA binding protein that binds nearly all mRNAs. Jerky may be a "group specific" mRNA binding protein (Keene, 2001) that associates with a subset of the global mRNA population and that have some sequence preference but no unique mRNA sequence recognition. Consistent with these data, Jerky has a high affinity to poly $(\mathrm{U})$ and somewhat less to $\operatorname{poly}(\mathrm{G})$ and poly(A). Domain searches revealed no known RNA binding motif within Jerky, and studies are under way to map the Jerky domain(s) involved in mRNA binding.

In summary, we describe a novel function for Jerky, a protein deficient in an animal model of inherited TLE. Specifically, Jerky is associated with translationally inactive mRNAs in the cytoplasm of neurons, and we hypothesize that a deficiency in Jerky leads to perturbations in the use of a currently unknown set of mRNAs. Even small changes in the use of mRNAs encoding channel and receptor proteins may result in hyperexcitability and seizures. Alternatively, mRNAs of developmentally important genes may be perturbed in Jerky-deficient mice resulting in the formation of intrinsically hyperexcitable neuronal networks. Indeed, it has been shown that alterations in gene expression in the hippocampus precede and accompany the manifestation of seizures in human and animal models of TLE (Blumcke et al., 2000; Murray et al. 2000; Brooks-Kayal et al., 2001). Data described here implicate that perturbations in the use of a subset of mRNAs in neurons may be a disease mechanism in focal epilepsies.

\section{REFERENCES}

Berkovic SF, Howell RA, Hopper JL (1994) Familial temporal lobe epilepsy: a new syndrome with adolescent/adult onset and a benign course. In: Epileptic seizures and syndromes (Wolf P, ed), pp 257-263. London: Libbey.
Berkovic SF, McIntosh A, Howell RA, Mitchell A, Sheffield LJ, Hopper JL (1996) Familial temporal lobe epilepsy: a common disorder identified in twins. Ann Neurol 40:227-235.

Blumcke I, Becker AJ, Klein C, Scheiwe C, Lie AA, Beck H, Waha A, Friedl MG, Kuhn R, Emson P, Elger C, Wiestler OD (2000) Temporal lobe epilepsy associated up-regulation of metabotropic glutamate receptors: correlated changes in mGluR1 mRNA and protein expression in experimental animals and human patients. J Neuropathol Exp Neurol 59:1-10.

Brooks-Kayal AR, Shumate MD, Jin H, Rikhter TY, Kelly ME, Coulter DA (2001) $\gamma$-Aminobutyric acid (A) receptor subunit expression predicts functional changes in hippocampal dentate granule cells during postnatal development. J Neurochem 77:1266-1278.

Ceman S, Brown V, Warren ST (1999) Isolation of an FMRP-associated messenger ribonucleoprotein particle and identification of nucleolin and the fragile X-related proteins as components of the complex. Mol Cell Biol 19:7925-7932.

Cendes F, Lopes-Cendes I, Andermann E, Andermann F (1998) Familial temporal lobe epilepsy: a clinically heterogeneous syndrome. Neurology 50:554-557.

Cooke CA, Bernat RL, Earnshaw WC (1990) CENP-B: a major human centromere protein located beneath the kinetochore. J Cell Biol 110:1475-1488.

Cutts SM, Fowler KJ, Kile BT, Hii LL, O’Dowd RA, Hudson DF, Saffery R, Kalitsis P, Earle E, Choo KH (1999) Defective chromosome segregation, microtubule bundling, and nuclear bridging in inner centromere protein gene (Incenp)-disrupted mice. Hum Mol Genet 8:1145-1155.

Dingwall C, Ernberg I, Gait MJ, Green SM, Heaphy S, Karn J, Lowe AD, Singh M, Skinner MA (1990) HIV-1 tat protein stimulates transcription by binding to a U-rich bulge in the stem of the TAR RNA structure. EMBO J 9:4145-4153.

Dobbelstein M, Shenk T (1995) In vitro selection of RNA ligands for the ribosomal L22 protein associated with Epstein-Barr virus-expressed RNA by using randomized and cDNA-derived RNA libraries. J Virol 69:8027-8034.

Donovan GP, Harden C, Gal J, Ho L, Sibille E, Trifiletti R, Gudas LJ, Toth M (1997) Sensitivity to jerky gene dosage underlies epileptic seizures mice. J Neurosci 17:4562-4569.

Earnshaw WC, Rothfield N (1985) Identification of a family of human centromere proteins using autoimmune sera from patients with scleroderma. Chromosoma 91:313-321.

Earnshaw WC, Sullivan KF, Machlin PS, Cooke CA, Kaiser DA, Pollard TD, Rothfield NF, Cleveland DW (1987) Molecular cloning of cDNA for CENP-B, the major human centromere autoantigen. J Cell Biol 104:817-829.

Falconer MA, Serafetinides EA, Corsellis JA (1964) Etiology and pathogenesis of temporal lobe epilepsy. Arch Neurol 10:233-348.

Feng Y, Absher D, Eberhart DE, Brown V, Malter HE, Warren ST (1997) FMRP associates with polyribosomes as an mRNP, and the I304N mutation of severe fragile $\mathrm{X}$ syndrome abolishes this association. Mol Cell 1:109-118.

Fowler KJ, Hudson DF, Salamonsen LA, Edmondson SR, Earle E, Sibson MC, Choo KH (2000) Uterine dysfunction and genetic modifiers in centromere protein B-deficient mice. Genome Res 10:30-41.

Gambardella A, Annesi G, De Fusco M, Patrignani A, Aguglia U, Annesi F, Pasqua AA, Spadafora P, Oliveri RL, Valentino P, Zappia M, Ballabio A, Casari G, Quattrone A (2000) A new locus for autosomal dominant nocturnal frontal lobe epilepsy maps to chromosome 1 . Neurology 55:1467-1471.

Guan KL, Dixon JE (1991) Eukaryotic proteins expressed in Escherichia coli: an improved thrombin cleavage and purification procedure of fusion proteins with glutathione S-transferase. Anal Biochem 192:262-267.

Hall KB, Kranz JK (1999) Nitrocellulose filter binding for determination of dissociation constants. Methods Mol Biol 118:105-114.

Howman EV, Fowler KJ, Newson AJ, Redward S, MacDonald AC, Kalitsis P, Choo KH (2000) Early disruption of centromeric chromatin organization in centromere protein A (Cenpa) null mice. Proc Natl Acad Sci USA 97:1148-1153.

Hudson DF, Fowler KJ, Earle E, Saffery R, Kalitsis P, Trowell H, Hill J, Wreford NG, de Kretser DM, Cancilla MR, Howman E, Hii L, Cutts SM, Irvine DV, Choo KH (1998) Centromere protein B null mice are mitotically and meiotically normal but have lower body and testis weights. J Cell Biol 141:309-319.

Ikeda A, Kunieda T, Miyamoto S, Fukuyama H, Shibasaki H (2000) Autosomal dominant temporal lobe epilepsy in a Japanese family. J Neurol Sci 176:162-165.

International Human Genome Sequencing Consortium (2001) Initial sequencing and analysis of the human genome. Nature 409:860-921.

Kapoor M, Montes de Oca Luna R, Liu G, Lozano G, Cummings C, Mancini M, Ouspenski I, Brinkley BR, May GS (1998) The cenpB gene is not essential in mice. Chromosoma 107:570-576.

Keene JD (2001) Ribonucleoprotein infrastructure regulating the flow of 
genetic information between the genome, the proteome. Proc Natl Acad Sci USA 98:7018-7024.

Lin Q, Taylor SJ, Shalloway D (1997) Specificity and determinants of Sam68 RNA binding: implications for the biological function of K homology domain. J Biol Chem 272:27274-27280.

Liu W, Yoon J, Burg M, Chen L, Pak WL (1995) Molecular characterization of two Drosophila guanylate cyclases expressed in the nervous system. J Biol Chem 270:12418-12427.

Moore T, Hecquet S, McLellann A, Ville D, Grid D, Picard F, Moulard B, Asherson P, Makoff AJ, McCormick D, Nashef L, Froguel P, Arzimanoglou A, LeGuern E, Bailleul B (2001) Polymorphism analysis of JRK/JH8, the human homologue of mouse jerky, and description of a rare mutation in a case of CAE evolving to JME. Epilepsy Res 46:157-167.

Morita R, Miyazaki E, Fong CY, Chen XN, Korenberg JR, DelgadoEscueta AV, Yamakawa K (1998) JH8, a gene highly homologous to the mouse jerky gene, maps to the region for childhood absence epilepsy on 8q24. Biochem Biophys Res Commun 248:307-314.

Muro Y, Masumoto H, Yoda K, Nozaki N, Ohashi M, Okazaki T (1992) Centromere protein $\mathrm{B}$ assembles human centromeric alpha-satellite DNA at the 17-bp sequence, CENP-B box. J Cell Biol 116:585-596.

Murray KD, Isackson PJ, Eskin TA, King MA, Montesinos SP, Abraham LA, Roper SN (2000) Altered mRNA expression for brain-derived neurotrophic factor and type II calcium/calmodulin-dependent protein kinase in the hippocampus of patients with intractable temporal lobe epilepsy. J Comp Neurol 418:411-422.

Nabors LB, Gillespie GY, Harkins L, King PH (2001) HuR, a RNA stability factor, is expressed in malignant brain tumors, binds to adenine-, uridine-rich elements within the $3^{\prime}$ untranslated regions of cytokine, angiogenic factor mRNAs Cancer Res 61:2154-2161.

Papa M, Bundman MC, Greenberger V, Segal M (1995) Morphological analysis of dendritic spine development in primary cultures of hippocampal neurons. J Neurosci 15:1-11.

Perez-Castro AV, Shamanski FL, Meneses JJ, Lovato TL, Vogel KG, Moyzis RK, Pedersen R (1998) Centromeric protein B null mice are viable with no apparent abnormalities. Dev Biol 201:135-143.

Picard F, Baulac S, Kahane P, Hirsch E, Sebastianelli R, Thomas P, Vigevano F, Genton P, Guerrini R, Gericke CA, An I, Rudolf G, Herman A, Brice A, Marescaux C, LeGuern, E (2000) Dominant partial epilepsies: a clinical, electrophysiological and genetic study of 19 Eur families. Brain 123:1247-1262.

Poza JJ, Saenz A, Martinez-Gil A, Cheron N, Cobo AM, Urtasun M, Marti-Masso JF, Grid D, Beckmann JS, Prud'homme JF, Lopez de Munain A (1999) Autosomal dominant lateral temporal epilepsy: clinical and genetic study of a large Basque pedigree linked to chromosome 10q. Ann Neurol 45:182-188.

Saenz A, Galan J, Caloustian C, Lorenzo F, Marquez C, Rodriguez N, Jimenez MD, Poza JJ, Cobo AM, Grid D, Prud'homme JF, Lopez de Munain A (1999) Autosomal dominant nocturnal frontal lobe epilepsy in a Spanish family with a Ser252Phe mutation in the CHRNA4 gene. Arch Neurol 56:1004-1009.

Sullivan KF, Glass CA (1991) CENP-B is a highly conserved mammalian centromere protein with homology to the helix-loop-helix family of proteins. Chromosoma 100:360-370.

Toth M, Grimsby J, Buzsaki G, Donovan GP (1995) Epileptic seizures caused by inactivation of a novel gene, jerky, related to centromere binding protein-B in transgenic mice. Nat Genet 11:71-75.

Yoda K, Kitagawa K, Masumoto H, Muro Y, Okazaki T (1992) A human centromere protein, CENP-B, has a DNA binding domain containing four potential alpha helices at the $\mathrm{NH} 2$ terminus, which is separable from dimerizing activity. J Cell Biol 119:1413-1427. 